\title{
Erektil disfonksiyon ve/veya prematüre ejakülasyon tanısı alan erkeklerde çift uyumunu yordayan değișkenler nelerdir? Cinsiyet rolleri, depresyon, anksiyete, stres, kișilik özellikleri ve benlik saygısı
}

What are the variables predicting dyadic adjustment in men with erectile dysfunction and/or premature ejaculation? Sex roles, depression, anxiety, stress, personality traits and self-esteem

Gökay Ata®, Özden Yalçınkaya Alkar®, Fatih Hızlıe, Halil Basar²ø

\section{öz}

AMAÇ: Bu araştırmanın amacı erektil disfonksiyon ve/veya prematüre ejakülasyon tanısı alan bireylerin, çift uyumlarını yordayan değişkenlerin belirlenmesidir. Bu amaçla çalışmaya cinsiyet rolleri, depresyon-anksiyete-stres ve kişilik özellikleri değişkenleri dahil edilmiştir.

GEREÇ ve YöNTEMLER: Yaşları 26-76 aralığında, erektil disfonksiyon ve/veya prematüre ejakülasyon tanısı alan evli 101 kişiden veri toplanmıştır. Değişkenler arası ilişkileri incelemek amacıyla korelasyon analizi ve hiyerarşik regresyon analizi gerçekleştirilmiştir.

BULGULAR: Kadınsılık cinsiyet rolü, depresyon-anksiyete-stres, nörotisizm, deneyime açıklık ve olumsuz değerlik ile çiftlerin uyumu arasında anlamlı ilişkilerin olduğu bulgusu elde edilmiştir. Ayrıca çiftlerin uyumunun kadınsılık, deneyime açılık, olumsuz değerlik ve depresyon-anksiyete-stres değişkenleri tarafından yordanırken nörotisizm ve deneyime açıklık kişilik özelliklerinin çiftlerin uyumunu yordamadığı bulgusu elde edilmiştir.

SONUCุ: Erektil disfonksiyon ve/veya prematüre ejakülasyon tanısı alan bireylerin kadınsılık cinsiyet rolü ve deneyime açıklık kişilik özelliği arttıkça ilişki doyumu artarken; olumsuz değerlik kişilik özelliği ve depresyon-anksiyete-stres düzeyi arttıkça evlilik doyumunun azaldığı görülmektedir.

Anahtar Kelimeler: Çiftlerin uyumu, duygu durum, erektil disfonksiyon, kişilik özellikleri, prematüre ejakülasyon

'Ankara Yıldırım Beyazıt Üniversitesi Insan ve Toplum Bilimleri Fakültesi, Psikoloj Anabilim Dalı, Ankara, Türkiye

${ }^{2}$ Onkoloji Eğitim ve Araștırma Hastanesi Üroloji Kliniği, Ankara, Türkiye

Yazışma Adresi/ Correspondence:

Klinik Psk. Gökay Ata

Casa Towers Sitesi, A Blok No: 3a 34775 Ümraniye, Türkiye

Tel: $\quad+905056633962$

E-mail: goekayata@yahoo.com

Geliş/ Received: $\quad 29.04 .2021$

Kabul/ Accepted: $\quad 06.07 .2021$

\section{ABSTRACT}

OBJECTIVE: The aim of this research is to determine the variables that predict dyadic adjustment of individuals diagnosed with erectile dysfunction and/or premature ejaculation. For this purpose, sex roles, depression-anxiety-stress and personality traits variables were included in the study.

MATERIAL and METHODS: Data were collected from 101 married individuals, aged 26-76, diagnosed with erectile dysfunction and/or premature ejaculation. Then, correlation analysis and then hierarchical regression analysis were performed to examine the relationships between variables.

RESULTS: It was found that there were significant relationships between the sex role of femininity, depression-anxiety-stress, neuroticism, openness to experience, negative valence and dyadic adjustment. In addition, it was found that neuroticism and openness to experience did not predict dyadic adjustment, while femininity, openness to experience, negative valence, and depression-anxiety-stress variables predicted dyadic adjustment.

CONCLUSION: While the relationship satisfaction of individuals diagnosed with erectile dysfunction and/or premature ejaculation increases as the feminine sex role and personality trait open to experience increase; It is observed that as the negative valence personality trait and depression-anxiety-stress level increase, marital satisfaction decreases.

Keywords: Dyadic adjustment, affect, erectile dysfunction, personality traits, premature ejaculation 
yer aldığı çalışmaların incelenmesi ve çift uyumuna olası etkileri hakkında bilgiler sağlanması amaçlanmıştır.

Erektil disfonksiyon tatmin edici bir şekilde cinsel performans yaşamak amacıyla gerekli olan ereksiyonu başaramama ya da sürdürememe olarak ifade edilmektedir. ${ }^{[1]}$

1995-2025 yıllarını kapsayacak şekilde gerçekleştirilen boylamsal bir çalışmada, dünya genelindeki kayıt altında bulunan erektil disfonksiyon sayısının 152 milyon olduğu ve bu durumun yansımalarının 2025yılında 322 milyonu bulabileceği ifade edilmiştir. ${ }^{[2]}$

Erektil disfonksiyona yönelik yapılan epidemiyolojik çalışmalar, erkeklerin yaklaşık olarak \%5 ila \%20'sinin orta ve şiddetli düzeyde erektil disfonksiyona sahip olduğunu göstermiştir. ${ }^{[3]}$

Erektil disfonksiyon ile çiftlerin uyumunun ilişkisine yönelik olarak alanyazınında bulunan çalışmalara bakıldığından ise erektil disfonksiyon ile çiftlerin uyumu arasından negatifyönde anlamlı ilişkilerin olduğu bulgusunun elde edildiği görülmüştür. ${ }^{[4-6]}$

Prematüre ejakülasyon, minimum uyaranla veya daha erken, penetrasyondan önce veya sonra, rahatsızlığa neden olan ve boşalma üzerinde kontrolün çok az ya da hiç olmadığı bir durum olarak tanımlanmıştır. ${ }^{[7]}$ Genel olarak prematüre ejakülasyon süresi, ejakülasyonu kontrol etme ya da geciktirmedeki başarısızlık ile karakterize olmaktadır. ${ }^{[8]}$

Prematüre ejakülasyonun yaygınlığı $\% 20$ ila \%30 aralığındadir. $^{[9]}$

Prematüre ejakülasyon ile çiftlerin uyumuna yönelik olarak alanyazınında gerçekleştirilen çalışmalar incelendiğinde prematüre ejakülasyon ile çiftlerin uyumu arasında negatif yönde anlamlı ilişkilerin olduğu bulgusunun elde edildiği görülmüştür. ${ }^{[10-12]}$

Geleneksel olarak, erkeksilik ve kadınsılık devam eden bir sürekliliğin iki ayrı ucu olarak kavramsallaştırılmıştır. ${ }^{[13]}$ Erkeksi cinsiyet rolleri kendine güvenme, bağımsızlık, bireysellik, güçlü kişiliğe sahip olma, rekabetçilik, baskın olma, hırslı olma, girişkenlik ve liderlik gibi özellikleri barındırırken; kadınsı cinsiyet rolleri neşeli olma, nazik olma, utangaç olma, şefkatli olma, sadakat, çocukları sevme ve uysallık gibi özellikleri barındırmaktadır. ${ }^{[13]}$

Cinsiyet rolleri ile çiftlerin uyumu arasında yapılan çalışmalara yönelik olarak alanyazını incelendiğinde çiftlerin uyumu ile kadınsılık arasında pozitif yönde anlamlı ilişkilerin olduğu bulgusunun elde edildiği görülmüştür. ${ }^{[14-16]}$ Ayrıca bazı çalışmalarda ise belirli bir cinsiyet rolü yerine androjen (her iki role de sahip olmak) cinsiyet rolüne sahip olmanın, çiftlerin uyumu ile pozitif yönde anlamlı ilişkilere sahip olduğu bulgusu elde edilmiştir. ${ }^{[17-19]}$

Depresyon kişinin nasıl hissettiği, nasıl düşündüğü ve nasıl davrandığı konusunda kendisini duygusal, davranışa yönelik ya da bedensel belirtiler olarak sergileyen olumsuz etkileri olan tedavi edilebilir, yaygın ve ciddi bir duygu durum bozukluğudur. ${ }^{[20,21]}$ Depresyon mutsuzluğa, daha önceden keyif alınan etkinliklere yönelik ilgi kaybına, iştah değişimine, enerji kaybına, değersiz ve suçlu hissetmeye, konsantre olma güçlüklerine, ölüm ya da intihar düşüncelerine, uykuda güçlüğe ya da fazla uyumayla iş ve ev hayatında kişinin işlevselliğini olumsuz etkileyen bir takım duygusal ve fiziksel problemlerle beraber cinsel işlevde bozulmaya yol açmaktadır. ${ }^{[20]}$ Kişiler depresyonda olduklarında karamsar olmaya ve ruminatif (tekrarlayıcı) düşüncelere maruz kalabilmektedirler. ${ }^{[22]}$

Depresyon ve çiftlerin uyumuyla ilişkili olarak alanyazınındaki çalışmalar incelendiğinde depresyon ile çiftlerin uyumu arasında negatif yönde anlamlı ilişkilerin olduğu bulgusunun elde edildiği görülmüştür. ${ }^{[6,23,24]}$

Anksiyete, genellikle sorun çözme konusunda bireyi engelleyen, olayları değerlendirme konusunda akıl yürütme işlevlerini güçleştiren, bireyde bunalma, terleme, gerginlik ve göğüste daralma yaratan bir durumdur. ${ }^{[25]}$ Özellikle cinsel işlev bozukluklarında bireyin yaşadığı performans anksiyetesi ve genel anksiyete hem bozukluğu devam ettiren hem de bozukluğu meydana getiren unsurlar olarak rol oynayabilmektedir. ${ }^{[26]}$

Anksiyete ve çiftlerin uyumu ilişkisine yönelik olarak alanyazını incelendiğinde anksiyete ve çiftlerin uyumu arasında negatif yönde anlamlı ilişkilerin olduğu bulgusunun elde edildiği görülmüştür. ${ }^{[23,27,28]}$

Stres kavramı sıkıntı ve zorlanma gibi anlamlara gelerek zor durumlara yönelik bireyin yaşadığı direnç hali, çevrenin istekleriyle bireyin mevcut becerileri arasındaki uyumsuzluk ve uyuma yönelik çaba ile bireyin bir olay sonucunda yaşadığı psikolojik ya da fizyolojik gerginlik hali olarak tanımlanmaktadır. ${ }^{[29-31]}$

Stres ile çiftlerin uyumu arasındaki ilişkilere yönelik alanyazınındaki çalışmalar incelendiğinde stres ile çiftlerin uyumu arasında negatif yönde anlamlı ilişkilerin olduğu bulgusunun elde edildiği görülmüştür. ${ }^{[32-34]}$

Bireylerin sürekli olan bilişsel, duygusal ve davranışsal desenlerini ortaya koymak ve tanımlamak için kişiliğin beş faktörlü modeli ortaya atılmıştır. ${ }^{[35]}$ Beş faktörlü modelin bileşenleri ise dışadönüklük, deneyime açılık, nörotisizm, sorumluluk ve uyumluluktur. ${ }^{[36]}$ Beş faktörlü modelin diğer kişilik teorilerine geniş bir çerçeve sunduğu ve beş 
faktörün şemsiye kavramlar olarak rol üstlenebileceği, birçok özelliği içinde barındıracağı ifade edilmiştir. ${ }^{[37]}$

Çiftlerin uyumuyla kişilik özelliklerinin ilişkisine yönelik yapılan bir çalışmada da çift uyumunu yordama konusunda nörotisizm kişilik özelliğinin etkili olduğu bulgusu elde edilmiştir. ${ }^{[38]}$ Ayrıca sorumluluk kişilik özelliğinin her eşte de benzer seviyelerde olması evlilik uyumuyla pozitif yönde ilişkili olarak bulunmuştur. ${ }^{[39]}$ Yapılan başka bir çalışmada yüksek nörotisizm ve düşük uyumluluk ile evlilik tatmini arasında negatif yönde bir ilişki elde edilmiştir. ${ }^{[40]}$

Evlilik kavramı uzun yıllardan beri insanların birlikteliğine ek olarak aile ve topluluk anlamlarına da karşılık gelmektedir. ${ }^{[41]}$

Çiftler arasındaki tatminin gerçek ya da beklentideki bir ilişkide karşılıklı uyum ile alakalı olduğu ve bunun meydana gelebilmesi için rol beklentileriyle algılanan rol performansları arasında tutarsızlığın olmaması gerektiğini ifade edilmiştir. ${ }^{[42]}$

Çiftlerin uyumu kavramı da benzer şekilde çiftler arasındaki etkileşime, paylaşıma, iletişime ve bunların zamanla ortaya çıkan değişimlerine karşılık gelmekte ve bu yaklaşımda vurgu yapılan nokta ise ilişkilerdeki özelliklerin, etkileşimlerin geçirdiği değişimdir. ${ }^{[43]}$

\section{GEREÇ Ve YÖNTEMLER}

\section{Katılımcılar}

Araştırmaya, 18 yaş ve üzeri evli olan ve üroloji polikliniğine başvuran erektil disfonksiyon ve/veya prematüre ejakülasyon bozukluğu tanısı alan 101 kişi katılmıştır. Yaş aralığ 26-76 (ss: 11,66, ort: 51,53) olan örneklem grubunun 31'i
(\%29,8) ilkokul, 13’ü (\%12,5) ortaokul, 25’i (\%24) lise, 32 'si $(30,8)$ üniversite eğitimine sahip olduğunu belirtmiştir. Ayrıca katılımcılardan 32'si $(\% 30,8)$ erektil disfonksiyona, 40’1 $(\% 38,5)$ prematüre ejakülasyona ve 29 'u da (\%28) her iki bozukluğa birden sahip olduğunu belirtmiştir. Tablo 1'de katılımcıların sosyodemografik özelliklerine ait bilgilere yer verilmektedir.

\section{Materyaller}

\section{Demografik Bilgi Formu}

Bu formda cinsiyet, yaş, eğitim düzeyi, evlilik süresi, mevcut cinsel işlev bozukluğuyla ilişkili maddeler yer almaktadır

\section{Bem Cinsiyet Rolü Envanteri}

Orijinal envanter erkeksi ve kadınsı özellikleri değerlendirmek amacıyla geliştirilmiştir. ${ }^{[4]}$ Geliştirilen envanterin Cronbach alfa değerleri 0,75 ve 0,90 olarak bulunmuştur. Ölçüm aracı yedili likert tarzda puanlanmaktadır. Envanterin Türkçeye uyarlama, geçerlik ve güvenirlik çalışmaları gerçekleştirilmiş ve Türkçe formunun güvenirlik kat sayıları 0,73 ve 0,75 olarak bulunmuştur. ${ }^{[45]}$

\section{Depresyon-Anksiyete-Stres Ölçeği-21}

Ölçek dörtlü likert yapıda puanlanmakta ve kırk iki maddeden oluşmaktadır. ${ }^{[46]}$ Kırk iki madde olarak geliştirilen ölçek aynı ölçümü verebilmek adına yirmi bir maddeye indirilmiştir. ${ }^{[4]}$ Orijinal formunun Cronbach alfa değerleri depresyon boyutu için 0,74 , anksiyete boyutu için 0,81 ve stres boyutu için 0,58 olarak bulunmuştur. Ölçeğin Türkçe formunun Cronbach alfa değerleri depresyon boyutu için 0,87 , anksiyete boyutu için 0,85 ve stres boyutu için 0,81 'dir. ${ }^{[48]}$

Tablo 1. Demografik bilgilere ilişkin betimsel istatistikler

\begin{tabular}{|c|c|c|c|c|c|c|}
\hline Demografik Özellikler & $N$ & Ortalama & SS. & Min. & Max. & Yüzde (\%) \\
\hline Yaş & & 51,53 & 11,6 & 26 & 76 & \\
\hline \multicolumn{7}{|l|}{ Eğitim Durumu } \\
\hline Ilkokul & 31 & & & & & 29,8 \\
\hline Ortaokul & 13 & & & & & 12,5 \\
\hline Lise & 25 & & & & & 24 \\
\hline Üniversite & 32 & & & & & 30,8 \\
\hline Evlilik Süresi (Ay) & & 315,35 & 161,18 & 3 & 720 & \\
\hline \multicolumn{7}{|l|}{ Cinsel İşlev Bozukluğu } \\
\hline PE & 40 & & & & & 38,5 \\
\hline ED & 32 & & & & & 30,8 \\
\hline PE ve ED & 29 & & & & & 28 \\
\hline
\end{tabular}

$P E$, prematüre ejakülasyon; $E D$, erektil disfonksiyon. 


\section{Temel Kișilik Özellikleri Ölçeği}

Ölçek altı farklı kişilik faktörünü değerlendirmektedir. Bunlar: Dişadönüklük, sorumluluk, uyumluluk, nörotisizm, deneyime açıklık ve olumsuz değerliktir. Kırk beş maddeden oluşan ölçek beşli Likert yapıda puanlanmaktadır ve alt boyutlarının Cronbach alfa değerleri sırasıyla; dışadönüklük için 0,89 , sorumluluk için 0,85 , uyumluluk için 0,85 , nörotisizm için 0,83 , deneyime açıllık için 0,80 ve olumsuz değerlik boyutu için 0,71 şeklinde bulunmuştur. ${ }^{[49]}$

\section{Rosenberg Benlik Saygısı Ölçeği}

Orijinal ölçek on maddeden oluşmakta ve dörtlü likert yapıda puanlanmaktadır. ${ }^{[50]}$ Ölçekten alınan yüksek puanlar yüksek benlik saygısını ifade etmektedir. Orijinal ölçeğin Cronbach alfa değeri 0,72 olarak bulunmuştur. Ölçeğin Türkçe formunun Cronbach alfa değeri ise 0,71 olarak bulunmuştur. ${ }^{[51]}$

\section{Çiftler Uyum Ölçeği}

Otuz iki madde olan ölçek beşli Likert yapıda puanlanmaktadır. ${ }^{[43]}$ Ölçeğin alt boyutları çift fikir birliği, duyguların ifadesi, çift tatmini ve çift birlikteliğidir. Türkçeye uyarlaması yapılmış olan ölçeğin Cronbach alfa değeri 0,92 olarak bulunmuştur. ${ }^{[52]}$

\section{ișlem}

Araştırmaya başlamadan önce Ankara Yıldırım Beyazıt Üniversitesi Etik Kurulu'ndan etik izin alınmış ve üroloji polikliniğine başvuran prematüre ejakülasyon ve/veya erektil disfonksiyon tanısı alan kişilerden araştırmaya katılmaya gönüllü olan katılımcılara gerekli bilgiler verilmiştir.
Tüm verilerin toplanmasının ardından ölçüm araçları araştırmacı tarafından puanlanıp analize uygun hale getirilmiş ve SPSS 22 istatistik programı yardımıla gerekli korelasyon ve regresyon analizleri gerçekleştirilmiştir.

Elde edilen verilerin parametrik analizlere uygunluğunu test etmek amacıyla Histogram grafikleri ve z-puanları incelenmiştir. Yapılan incelemelerin ardından elde edilen verilerin normale yakın dağılım sergilediği görülmüştür. $\mathrm{Bu}$ işlemin ardından kayıp veri analizi gerçekleştirilmiş ve kayıp veri sayısı \%5'in altında bulunan 8 katılımcıya boş bırakılan maddelere yönelik olarak grup ortalamaları atanmiştır. ${ }^{[53]}$

\section{BULGULAR}

\section{Çalıșmadaki Değișkenler Arasındaki Korelasyon Analizleri}

Çalışmada yer alan değişkenler arası korelasyonları incelemek amaciyla Pearson korelasyon analizi gerçekleştirilmiştir. Analiz sonucunda elde edilen bulgular Tablo 2'de sunulmuştur.

Çiftlerin uyumuyla kadınsılık $(r=0,42, p<0,01)$ ve deneyime açıklık $(r=0,23, p<0,05)$ arasında pozitif yönde anlamlı bir ilişki bulunurken; çiftlerin uyumuyla depresyon-anksiyete-stres $(r=-0,33, p<0,01)$, nörotisizm $(r=-0,27, p<0,01)$ ve olumsuz değerlik $(r=-0,23, p<0,05)$ arasında negatif yönde anlamlı bir ilişki olduğu gözlenmektedir.

Kadınsılık ile erkeksilik ( $r=0,30, \quad p<0,01)$, uyumluluk $(r=0,42, p<0,01)$ ve deneyime açıllık $(r=0,23, p<0,05)$ arasında pozitif yönde anlamlı bir ilişki olduğu gözlenmektedir.

Tablo 2. Değişkenler arasındaki korelasyon analizi sonuçları

\begin{tabular}{|c|c|c|c|c|c|c|c|c|c|c|c|}
\hline & $C ̧ U$ & Kadınsılık & Erkeksilik & $B S$ & DAS & Dışadönüklük & Sorumluluk & Uyumluluk & Nörotisizm & $\begin{array}{l}\text { Deneyime } \\
\text { açıklık }\end{array}$ & $\begin{array}{l}\text { Olumsuz } \\
\text { değerlik }\end{array}$ \\
\hline ÇU & - & & & & & & & & & & \\
\hline Kadınsılık & $0,42 * *$ & - & & & & & & & & & \\
\hline Erkeksilik & 0,15 & $0,30 * *$ & - & & & & & & & & \\
\hline BS & $-0,19$ & 0,13 & $-0,01$ & - & & & & & & & \\
\hline DAS & $-0,33 * *$ & 0,00 & 0,01 & $0,35 * *$ & - & & & & & & \\
\hline Dışadönüklük & 0,05 & $-0,00$ & $-0,01$ & 0,08 & 0,17 & - & & & & & \\
\hline Sorumluluk & 0,08 & 0,09 & $0,32 * *$ & 0,11 & 0,14 & $0,29 * *$ & - & & & & \\
\hline Uyumluluk & 0,11 & $0,42 * *$ & $0,20 *$ & 0,16 & 0,17 & 0,06 & 0,19 & - & & & \\
\hline Nörotisizm & $-0,27 * *$ & $-0,15$ & 0,04 & $0,21^{*}$ & $0,58 * *$ & 0,06 & $-0,01$ & 0,10 & - & & \\
\hline $\begin{array}{l}\text { Deneyime } \\
\text { açıklık }\end{array}$ & $0,23 *$ & $0,23 *$ & $0,25 * *$ & 0,01 & 0,07 & $-0,06$ & $0,21 *$ & $0,50 * *$ & $-0,11$ & - & \\
\hline $\begin{array}{l}\text { Olumsuz } \\
\text { değerlik }\end{array}$ & $-0,23 *$ & $-0,19$ & $-0,19$ & 0,07 & 0,03 & $-0,07$ & $-0,02$ & $-0,18$ & $0,37 * *$ & 0,05 & - \\
\hline
\end{tabular}

${ }^{*} p<0,05 ;{ }^{*} p<0,01 ;$ ÇU, çiftlerin uyumu; BS, benlik saygısı; DAS, depresyon-anksiyete-stres. 
Erkeksilik ile sorumluluk $(r=0,32, \quad p<0,01)$, uyumluluk $(r=0,20, p<0,05)$ ve deneyime açıklık $(r=0,25$, $p<0,01)$ arasında pozitif yönde anlamlı bir ilişki olduğu gözlenmektedir.

Benlik saygısıla depresyon-anksiyete-stres $\quad(r=0,35$, $p<0,01)$ ve nörotisizm $(r=0,21, p<0,05)$ arasında pozitif yönde anlamlı bir ilişki olduğu gözlenmektedir.

Depresyon-anksiyete-stres ile nörotisizm $(r=0,58, p<0,01)$ arasında; dişadönüklük ile sorumluluk $(r=0,29, p<0,01)$ arasında; deneyime açıklık ile sorumluluk $(r=0,21, p<0,05)$ ve uyumluluk $(r=0,50, p<0,01)$ arasında; nörotisizm ile olumsuz değerlik $(r=0,37, p<0,01)$ arasında pozitif yönde anlamlı ilişkilerin olduğu gözlenmektedir.

\section{Çift Uyumu Yordayan Değișkenlere ilișkin Regresyon Analizi Sonuçları}

Çiftlerin uyumunu yordayan değişkenleri incelemek amacıyla hiyerarşik regresyon analizi gerçekleştirilmiş ve analizin ilk adımında kadınsılık değişkeni; ikinci adımında depresyon- anksiyete-stres değişkeni; üçüncü adımında nörotisizm değişkeni; dördüncü adımında deneyime açıklık değişkeni ve son olarak beşinci adımında ise olumsuz değerlik değişkeni analize dâhil edilmiştir. Analize dahil edilen değişkenlerin sıralaması çiftlerin uyumuyla gösterdikleri korelasyon düzeylerine göre belirlenmiştir. Regresyon analizi sonuçları Tablo 3'te sunulmuştur.

Gerçekleştirilen hiyerarşik regresyon analizi sonucuna göre, ilk adımda kadınsılığın çiftlerin uyumunun \%18'ini açıkladığı bulunmuştur. Bununla beraber kadınsılığın $(\beta=0,42, p<0,01)$ çiftlerin uyumu üzerinde anlamlı bir yordayıcılık üstlendiği görülmüştür. Başka deyişle yüksek düzeyde kadınsılık cinsiyet rolleri gösteren bireylerin uyumlarının daha yüksek olduğu ifade edilebilir. İkinci adımda, modele depresyon-anksiyete-stres dâhil edilmiş ve toplam varyansın \%29'unun açıklandığı bulunmuştur. Depresyon-anksiyete-stresin modele dâhil edildiği bu adımda, depresyon-anksiyete-stresin $(\beta=-0,33, \quad p<0,01)$ çiftlerin uyumunun anlamlı bir yordayıcısı olduğu görülmüştür. Başka deyişle yüksek düzeyde yaşanılan depresyon-anksiyete-stres çiftlerin uyumunun daha düşük olmasına yol açıyor şeklinde ifade edilebilir. Üçüncü adımda, modele nörotisizm dâhil edilmiş ve toplam varyansın \%29'unun açıklanmaya devam ettiği bulunmuştur. Nörotisizmin analize dâhil edildiği bu adımda, nörotisizmin çiftlerin uyumunun anlamlı bir yordayıcısı olmadığı görülmüştür. Dördüncü adımda, modele deneyime açıklık dâhil edilmiş ve toplam varyansın \%31'inin açıklandığ1 bulunmuştur. Deneyime açıklığın çiftlerin uyumunun

Tablo 3. Çiftlerin uyumunu yordayan değişkenlere ilişkin hiyerarşik regresyon analizi sonuçları

\begin{tabular}{|c|c|c|c|c|c|c|}
\hline Model & Yordayıcı & $F$ & b & $t$ & $R^{2}$ & $R^{2}$ değiş̧imi \\
\hline 1. & $\begin{array}{c}\text { Sabit } \\
\text { Kadınsılık }\end{array}$ & $22,44 * *$ & 0,42 & $\begin{array}{c}0,18 \\
4,74^{* *}\end{array}$ & 0,18 & 0,18 \\
\hline \multirow{3}{*}{2.} & Sabit & $20,42^{* *}$ & & 0,59 & 0,29 & 0,11 \\
\hline & Kadınsılık & & 0,42 & $5,06 * *$ & & \\
\hline & DAS & & $-0,33$ & $-3,91 * *$ & & \\
\hline \multirow{4}{*}{3.} & Sabit & $13,51 * *$ & & 0,63 & 0,29 & 0,00 \\
\hline & Kadınsılık & & 0,42 & $4,91 * *$ & & \\
\hline & DAS & & $-0,31$ & $-3,01 * *$ & & \\
\hline & Nörotisizm & & $-0,02$ & $-0,24$ & & \\
\hline \multirow{5}{*}{4.} & Sabit & $11,28 * *$ & & $-0,07$ & 0,31 & 0,02 \\
\hline & Kadınsılık & & 0,39 & $4,50 * *$ & & \\
\hline & DAS & & $-0,34$ & $-3,30 * *$ & & \\
\hline & Nörotisizm & & 0,01 & 0,06 & & \\
\hline & Deneyime açıklık & & 0,16 & 1,90 & & \\
\hline \multirow{6}{*}{5.} & Sabit & $10,30 * *$ & & 0,32 & 0,34 & 0,03 \\
\hline & Kadınsılık & & 0,36 & $4,20 * *$ & & \\
\hline & DAS & & $-0,40$ & $-3,80 * *$ & & \\
\hline & Nörotisizm & & 0,11 & 1,00 & & \\
\hline & Deneyime açıklık & & 0,20 & $2,27^{*}$ & & \\
\hline & Olumsuz değerlik & & $-0,20$ & $-2,15^{*}$ & & \\
\hline
\end{tabular}

* $p<0,05 ; * * p<0,01 ;$ DAS, depresyon-anksiyete-stres. 
anlamlı bir yordayıcısı olmadığı görülmüştür. Son olarak beşinci adımda, modele olumsuz değerlik dâhil edilmiş ve toplam varyansın \%34'ünün açıklandığı bulunmuştur. Olumsuz değerliğin $(\beta=-0,20, p<0,05)$ çiftlerin uyumunun anlamlı bir yodayıcısı olduğu görülmüştür. Başka deyişle olumsuz değerliğin yüksek olduğu bireylerde çiftlerin uyumunun düşük olacağı ifade edilebilir.

\section{TARTIȘMA}

Mevcut çalışmada depresyon-anksiyete-stres ayrı ayrı değişkenler olmak yerine bir bütün olarak ele alınmış ve çiftlerin uyumuyla arasında negatif yönde anlamlı bir ilişkinin olduğu ve depresyon-anksiyete-stresin çiftlerin uyumunu anlamlı bir şekilde yordadığı bulgusu elde edilmiştir. Başka deyişle depresyon-anksiyete-stresin arttığı durumlarda çiftlerin uyumu azalmakta ve depresyon-anksiyete-streste yaşanılan bu artış çiftlerin uyumu olumsuz olarak etkilemektedir. Bu bulguyla paralel bir şekilde alanyazınındaki çalışmalar da incelendiğinde çiftlerin uyumuyla depresyon-anksiyete-stres arasında negatif yönde anlamlı bir ilişkinin olduğu bulgusunun elde edildiği görülmüştür. ${ }^{[6,23,28,54]}$

Bir diğer değişken olan cinsiyet rolleri ile çiftlerin uyumuna yönelik olarak gerçekleştirilen analizler sonucunda kadınsılık cinsiyet rolüyle çiftlerin uyumu arasında pozitif yönde anlamlı bulguların olduğu ve kadınsılık cinsiyet rolünün çiftlerin uyumunu anlamlı bir şekilde yordadığı bulgusu elde edilmiştir. Alanyazını incelendiğinde kadınsılık cinsiyet rolüyle çiftlerin uyumu arasında pozitif yönde anlamlı ilişkilerin olduğuna yönelik bulguların elde edildiği görülmektedir. ${ }^{[14-16]} \mathrm{Bu}$ durumun meydana gelmesinde özellikle merhamet, şefkat vb. duyguların yoğunlukta olduğu bir cinsiyet rolünün uyumu olumlu yönde etkileyeceği düşünülmektedir. Bundan ötürü erkeksilik cinsiyet rolünün ilişkili dahi bulunmamasına rağmen kadınsılık cinsiyet rolünün anlamlı bir şekilde ilişkili olduğu ifade edilebilir. İlişkinin devamlılığı için partnerler arasındaki iletişimi de oldukça önemli bir şekilde etkileme olasılığı yüksek olan kadınsı cinsiyet rollerinin bu yüzden daha belirleyici olabileceği düşünülmektedir.

Mevcut çalışma kapsamında çiftlerin uyumuyla ilişkili bulunan son değişken olan temel kişilik özellikleri ile çiftlerin uyumu arasındaki ilişkilere yönelik gerçekleştirilen analizler sonucunda nörotisizm ve olumsuz değerlik ile çiftlerin uyumu arasında negatif yönde anlamlı ilişkilerin olduğu bulunurken; deneyime açıklık ile çiftlerin uyumu arasında pozitif yönde anlamlı bir ilişkinin olduğu bulgusu elde edilmiştir. Alanyazını incelendiğinde, mevcut çalışmayla paralel olarak nörotisizm ile çiftlerin uyumu arasında negatif yönde anlamlı ilişkilere rastlanılmıştır.
[55-57] Fakat nörotisizmin çiftlerin uyumunu yordamadığg 1 görülmüştür. Bundan dolayı, olumsuz duygu ifade etme sıklığıyla ve olumsuz olaylara odaklanmayla ilgili olan nörotisizmdeki artışın çiftlerin uyumunu azalttığı fakat bu durumun çiftlerin uyumu üzerinde herhangi bir belirleyiciliğinin olmadığı ifade edilebilir. Deneyime açılık ile çiftlerin uyumu arasında ise pozitif yönde anlamlı ilişkilere rastlanılmıştır. ${ }^{[58-60]}$ Alanyazını ile tutarlı olarak elde edilen bu bulguyla da yeni şeyler denemeye karşı açık olan ve cesaret gösteren partnerlerin bu isteklerinin fazlalığıyla uyumları arasındaki ilişkinin de fazla olacağı ifade edilebilir. Fakat bu etki ilişki düzeyinde bulunduğundan ötürü deneyime açık olmak başı başına çiftlerin uyumunu artırır şeklinde bir yorum yapılamamaktadır. Ayrıca, çalışmada olumsuz değerlik kişilik özelliğiyle çiftlerin uyumu arasında negatif yönde anlamlı bir ilişki olmasına rağmen alanyazını incelendiğinde bu konuyla ilgili herhangi bir bulguya rastlanılmamıştır. Bu durumun meydana gelmesinde de yaygın olarak beş faktörlü kişilik özelliğinin kullanılıyor olmasının ve Türkiye özelinde geliştirilmiş bir kişilik özelliği ölçüm aracının kullanılıyor olmasının etkili olduğu düşünülmektedir. Ayrıca, alanyazınında ve ülkemizde üniversite öğrencileriyle yapılan bir çalışmada olumsuz değerlik ile ilişkili olabilecek degisskenlerle çiftlerin uyumu ve çiftlerin arasındaki fonksiyonların işleyişine yönelik gerçekleştirilen çalışmalarda mevcut çalışmayla tutarlı bir şekilde negatif ilişki bulgusuna rastlanılmıştır. ${ }^{[61,62]}$

\section{SINIRLILIKLAR Ve ÖNERILER}

Öncelikle, çalışma öz bildirim formlarıyla gerçekleştirilmiştir. Katılımcilardan elde edilen bilgiler sadece kendi beyanlarına dayanan ölçüm araçlarından toplandığı için elde edilen bulguların güvenirliği anlamında daha detaylı çalışmaların yararlı olacağı düşünülmektedir. Çalışmada kullanılan örneklem grubunun klinik bir örneklem grubu olması ve belirli bir bozukluğu ya da bozuklukları sergiliyor olması mevcut çalışmanın önemli yönlerinden biri olarak düşünülmektedir. Fakat ileride yapılacak olan çalışmalarda örneklem sayısının artırılmasının elde edilen bulguların güvenirliği anlamında daha net bulgular ortaya koyacağı düşünülmektedir. Ayrıca, mevcut araştırma hastalığın sebeplerinden bağımsız bir biçimde, primer veya sekonder disfonksiyon, değişkenler ve hastalığın çift uyumuyla olan ilişkisini incelemek amacıyla gerçekleştirilmiştir. Bundan dolayı sonraki çalışmalarda hastalığın sebeplerini daha iyi incelemek amaciyla detaylı sorgulamalar yapmanın ve uyum üzerindeki etkinin daha detaylı araştırılmasının genellenebilirlik anlamında daha uygun olacağı düşünülmektedir. Bununla birlikte mevcut çalışma sadece cinsel işlev 
bozukluğuna sahip olan bireylerle yürütüldüğü için cinsel işlev bozukluğu sergilemeyen bireyler ile karşılaştırma yapma imkânı bulunamamışır. Bundan ötürü, ileride yapılacak çalışmalarda bozukluk sergilemeyen bireylerin de çalışmaya dâhil edilmesiyle beraber karşılaştırma yapma imkânı bulunabileceği düşünülmektedir. Böylece çiftlerin uyumu üzerinde cinsel işlev bozukluklarının etkisinin büyüklüğünü anlamak amacıyla daha detaylı bilgilerin alınabileceği düşünülmektedir.

\section{SONUÇ}

Sonuç olarak erektil disfonksiyon ve/veya prematüre ejakülasyon bozukluğu tanısı alan bireylerde depresyon-anksiyete-stres, kadınsılık, nörotisizm, deneyime açıklık ve olumsuz değerlik çiftlerin uyumunu yordamaktadır. Alanyazını incelendiğinde de bu yönde bulguların olduğu çalışmalara rastlamak mümkündür. Değişkenler arası anlamlı ilişkilerin bulunması ve bozuklukların çift uyumuyla olan ilişkilerin negatif yönde olması da aslında cinsel birliktelikten elde edilen doyumun evlilik doyumuna ya da çift uyumuna olan önemli etkisini gözler önüne sermektedir. Bundan ötürü bu iki bozukluğa yönelik yapılacak tedavi girişimlerine ek olarak depresyonu-anksiyeteyi-stresi azaltmaya yönelik yapılacak girişimler ve eğitimler gibi pek çok koruyucu ve tedavi edici faktörün çiftlerin uyumunun artırılmasında önemli bir rol oynayacağı düşünülmektedir. Bununla birlikte olumlu kişilik özelliklerinin varlığıyla beraber eşler arasında diyaloğun sürdürülebildiği bir çift ilişkisini sağlamanın hem tedavi edici hem de tedavinin bir çıktısı olabileceği düşünülmektedir.

\section{Etik Kurul Onayı}

Çalışma, Ankara Yıldırım Beyazıt Üniversitesi Etik Kurulu tarafından onaylandı. (onay tarihi ve sayısı: 13.02.2019/18).

\section{Hakem Değerlendirmesi}

Dış bağımsız.

\section{Çıkar Çatışması}

Yazarlar çıkar ilişkisi olmadığını beyan etmişlerdir.

\section{Finansal Destek}

Herhangi bir mali destek alınmamıştır.

\section{Ethics Committee Approval}

The study was approved by Ankara Yıldırım Beyazıt University Ethics Committee. (date and number of approval: 13.02.2019/18).

\section{Peer-review}

Externally peer-reviewed.

Conflict of Interest

No conflict of interest was declared by the authors.

\section{Financial Disclosure}

No financial support has been received.

\section{KAYNAKLAR}

1. National Institutes of Health. NIH Consensus Conference. Impotence. NIH consensus development panel on impotence. JAMA 1993;270:83-90. https://pubmed.ncbi.nlm.nih. gov/8510302/
2. Ayta IA, Mckinlay JB, Krane RJ. The likely worldwide increase in erectile dysfunction between 1995 and 2025 and some possible policy consequences. BJU Int 1999;84:50-6. [CrossRef]

3. Feldman HA, Goldstein I, Hatzichristou DG, Krane RJ, McKinlay JB. Impotence and its medical and psychosocial correlates: results of the Massachusetts Male Aging Study. J Urol 1994;151:54-61. [CrossRef]

4. Avasthi A, Grover S, Kaur R, Prakash O, Kulhara O. Impact of nonorganic erectile dysfunction on spouses: A study from India. J Sex Med 2010;7:3666-74. [CrossRef]

5. Hamilton LD, Van Dam D, Wassersug RJ. The perspective of prostate cancer patients and patients' partners on the psychological burden of androgen deprivation and the dyadic adjustment of prostate cancer couples. Psychooncology 2016;25:823-31. [CrossRef]

6. Oyekçin DG, Gülpek D, Sahin EM, Mete L. Depression, anxiety, body image, sexual functioning, and dyadic adjustment associated with dialysis type in chronic renal failure. Int J Psychiatry Med 2012;43:227-41. [CrossRef]

7. McMahon CG, Abdo C, Incrocci L, Perelman M, Rowland D, Waldinger M, Xin ZC. Disorders of orgasm and ejaculation in men. J Sex Med 2004;1:58-65. [CrossRef]

8. Hatzimouratidis K, Amar E, Eardley I, Giuliano F, Hatzichristou D, Montorsi F, et al. Guidelines on male sexual dysfunction: erectile dysfunction and premature ejaculation. Eur Urol 2010;57:804-14. [CrossRef]

9. Laumann EO, Nicolosi A, Glasser DB, Paik A, Gingell C, Moreira E, et al. Sexual problems among women and men aged 40-80 $y$ : prevalence and correlates identified in the Global Study of Sexual Attitudes and Behaviors. Int J Impot Res 2005;17:39-57. [CrossRef]

10. Peixoto MM, Nobre P. Distressing sexual problems and dyadic adjustment in heterosexuals, gay men, and lesbian women. J Sex Marital Ther 2016;42:369-81. [CrossRef]

11. Che Man M, Mohd Zin F, Che Alhadi S, Yaacob NM, Ismail SB. Randomized Clinical Trial Between Fluoxetine and Dapoxetine for Premature Ejaculation and Its Effect on Marital Relationship. Int Med J Malay 2021;20. [CrossRef]

12. Zerach G, Anat BD, Solomon Z, Heruti R. Posttraumatic symptoms, marital intimacy, dyadic adjustment, and sexual satisfaction among ex-prisoners of war. J Sex Med 2010;7:273949. [CrossRef]

13. Bem SL. The measurement of psychological androgyny. J Consult Clin Psychol 1974;42:155-62. https://citeseerx.ist.psu.edu/ viewdoc/download?doi=10.1.1.472.525\&rep=rep1 \& type=pdf

14. Antill JK. Sex role complementarity versus similarity in married couples. J Person Soc Psychol 1983;45:145-55. [CrossRef]

15. Isaac R, Shah A. Sex roles and marital adjustment in Indian couples. Int J Soc Psychiatry 2004;50:129-41. [CrossRef]

16. Lenz ER, Soeken KL, Rankin EA, Fischman SH. Sex-role attributes, gender, and postpartal perceptions of the marital relationship. ANS Adv Nurs Sci 1985;7:49-62. [CrossRef]

17. Davidson B, Sollie DL. Sex-role orientation and marital adjustment. Soc Behav Pers 1987;15:59-69. [CrossRef]

18. Murstein BI, Williams PD. Assortative matching for sex-role and marriage adjustment. Person Individ Diff 1985;6:195-201. [CrossRef]

19. Rosenzweig JM, Dailey DM. Dyadic adjustment/sexual satisfaction in women and men as a function of psychological sex role selfperception. J Sex Marital Ther 1989;15:42-56. [CrossRef]

20. APA. Diagnostic and statistical manual of mental disorders (DSM5); 2013. https://www.psychiatry.org/psychiatrists/practice/dsm

21. Demir V. Bilinçli farkındalık temelli kognitif terapi programının bireylerin depresif belirti düzeyleri üzerine etkisi. Psikoloji Çalışmaları 2015;35:15-26. https://dergipark.org.tr/tr/download/ article-file/409007 
22. Taycan O, Kutlu L, Çimen S, Aydın N. Bir üniversite hastanesinde çalıșan hemşirelerde depresyon ve tükenmișlik düzeyinin sosyodemografik özelliklerle ilişkisi. Anadolu Psikiyatri Derg 2006;7:100-8. [Erişim]

23. Brandão T, Brites R, Pires $M$, Hipólito J, Nunes O. Anxiety, depression, dyadic adjustment, and attachment to the fetus in pregnancy: Actor-partner interdependence mediation analysis. J Fam Psychol 2019;33:294. [CrossRef]

24. King KE, Arnett PA. Predictors of dyadic adjustment in multiple sclerosis. Mult Scler 2005;11:700-7. [CrossRef]

25. Köroğlu E. Klinik Psikopatoloji. Hekimler Yayın Birliği; 2016. s.115.

26. Hedon F. Anxiety and erectile dysfunction: a global approach to ED enhances results and quality of life. Int J Impot Res 2003;15:S169. [CrossRef]

27. Hwang RH. Effects of state-anxiety and dyadic adjustment on pregnant women's pregnancy stress. J Digital Convergence 2019;17:225-33. [CrossRef]

28. Midmer D, Wilson L, Cummings S. A randomized, controlled trial of the influence of prenatal parenting education on postpartum anxiety and marital adjustment. Fam Med 1995;27:200-5. https:// pubmed.ncbi.nlm.nih.gov/7774781/

29. Güçlü N. Stres yönetimi. GÜ Gazi Eğitim Fakültesi Derg 2001;21:91-109. https://dergipark.org.tr/tr/download/articlefile/77499

30. McGrath JG. Stress and Behavior in Organizations (Chap. 31). In: Dunnette MD, editor. Handbook of industrial and organizational psychology. Chicago: Rand McNally College Pub. Co.; 1976.

31. Işıkhan V, Kahramanoğlu E. Sosyal hizmet yöneticilerinin iş stres faktörleri. Sağlık ve Toplum 2002;12:79-86. https://app.trdizin. gov.tr/publication/paper/detail/TVRnNE56YzM

32. Baldoni F, Giannotti M, Casu G, Luperini V, Spelzini F. A Dyadic Study on Perceived Stress and Couple Adjustment During Pregnancy: The Mediating Role of Depressive Symptoms. J Fam Issues 2020;41:1935-55. [CrossRef]

33. Canzi E, Molgora S, Fenaroli V, Rosnati R, Saita E, Ranieri S. "Your stress is my stress": A dyadic study on adoptive and biological first-time parents. Couple and Family Psychology: Research and Practice 2019;8:197. [CrossRef]

34. Cournoyer A, Laurin JC, Daspe MÈ, Laniel S, Huppé AS. Conditional regard, stress, and dyadic adjustment in primiparous couples: A dyadic analysis perspective. J Soc Pers Relat 2021;38:1472-94. [CrossRef]

35. Trull TJ, Widiger TA, Lynam DR, Costa PT Jr. Borderline personality disorder from the perspective of general personality functioning. J Abnorm Psychol 2005;1 12:193-202. [CrossRef]

36. Peabody D, Goldberg LR. Some determinants of factor structures from personality-trait descriptors. J Pers Soc Psychol 1989;57:552_ 67. [CrossRef]

37. Goldberg LR. Language and individual differences: The search for universals in personality lexicons. Rev Pers Soc Psychol 1981;2:141-65. https://projects.ori.org//rg/PDFs_papers/ universals.lexicon.81.pdf

38. Bouchard G, Lussier Y, Sabourin S. Personality and marital adjustment: Utility of the five-factor model of personality. J Marriage Fam 1999;651-60. [CrossRef]

39. Nemechek S, Olson KR. Five-factor personality similarity and marital adjustment. Soc Behav Pers 1999;27:309-17. [CrossRef]

40. Gattis KS, Berns S, Simpson LE, Christensen A. Birds of a feather or strange birds? Ties among personality dimensions, similarity, and marital quality. J Fam Psychol 2004;18:564-74. [CrossRef]

41. Glenn ND. Quantitative research on marital quality in the 1980s: A critical review. J Marriage Fam 1990;818-31. [CrossRef]

42. Rollins BC, Cannon KL. Marital satisfaction over the family life cycle: A reevaluation. J Marriage Fam 1974;271-82. [CrossRef]
43. Spanier GB. Measuring dyadic adjustment: New scales for assessing the quality of marriage and similar dyads. J Marriage Fam 1976;15-28. [CrossRef]

44. Bem SL. Bem Sex Role Inventory: Professional manual. Palo Alto, CA: Consulting Psychologists Press; 1981.

45. Dökmen ZY. Bem Cinsiyet Rolü Envanteri kadinsilik ve erkeksilik ölçekleri Türkçe formunun psikometrik özellikleri. Kriz Derg 1999;7:27-40. https://dergipark.org.tr/tr/download/articlefile/595862

46. Lovibond PF, Lovibond SH. The structure of negative emotional states: Comparison of the Depression Anxiety Stress Scales (DASS) with the Beck Depression and Anxiety Inventories. Behav Res Ther 1995;33:335-43. [CrossRef]

47. Henry JD, Crawford JR. The short-form version of the Depression Anxiety Stress Scales (DASS-21): Construct validity and normative data in a large non-clinical sample. Br J Clin Psychol 2005;44:22739. [CrossRef]

48. Sarıçam H. The psychometric properties of Turkish version of Depression Anxiety Stress Scale-21(DASS-21) in health control and clinical samples. J Cogn Behav Psychother Res 2018;7:19-30. https://psycnet.apa.org/record/2018-67176-002

49. Gençöz T, Öncül Ö. Examination of personality characteristics in a Turkish sample: Development of basic personality traits inventory. J Gen Psychol 2012;139:194-216. [CrossRef]

50. Rosenberg M. Rosenberg self-esteem scale (RSE). Acceptance and commitment therapy. Measures Package 1965;61:52.

51. Çuhadaroğlu F. Adolesanlarda benlik saygısı. Uzmanlık Tezi, Hacettepe Üniversitesi Tip Fakültesi Psikiyatri Ana Bilim Dalı, Ankara; 1986.

52. Fışıloğlu H, Demir A. Applicability of the Dyadic Adjustment Scale for measurement of marital quality with Turkish couples. Eur J Psychol Assess 2000;16:214-8. [CrossRef]

53. Myers TA. Goodbye, listwise deletion: Presenting hot deck imputation as an easy and effective tool for handling missing data. Communication Methods Measures 2011;5:297-310. [CrossRef]

54. Rimmerman A, Turkel L, Crossman R. Perception of child development, child-related stress and dyadic adjustment: Pair analysis of married couples of young children with developmental disabilities. J Intel Dev Disabil 2003;28:188-95. [CrossRef]

55. Daspe MÈ, Sabourin S, Péloquin K, Lussier Y, Wright J. Curvilinear associations between neuroticism and dyadic adjustment in treatment-seeking couples. J Fam Psychol 2013;27:232-41. [CrossRef]

56. Egan SJ, Vinciguerra T, Mazzucchelli TG. The role of perfectionism, agreeableness, and neuroticism in predicting dyadic adjustment. Austral J Psychol 2015;67:1-9. [CrossRef]

57. Jacobson NS, Follette WC, McDonald DW. Reactivity to positive and negative behavior in distressed and nondistressed married couples. J Consult Clin Psychol 1982;50:706-14. [CrossRef]

58. Bouchard G, Arseneault JE. Length of union as a moderator of the relationship between personality and dyadic adjustment. Person Individ Diff 2005;39:1407-17. [CrossRef]

59. Brock RL, Dindo L, Simms LJ, Clark LA. Personality and dyadic adjustment: Who you think your partner is really matters. J Fam Psychol 2016;30:602-13. [CrossRef]

60. Nemechek S, Olson KR. Personality and marital adjustment. Psychol Rep 1996;78:26.

61. Öngün E. Üniversite öğrencilerinin kişilik özelliklerinin romantik ilişkileri üzerine etkisi. Marmara Üniversitesi, Sağlık Bilimleri Enstitüsü, Yüksek Lisans; 2016. http://genclikbirikimi.org/kunye33830-universite-ogrencilerinin-kisilik-ozelliklerinin-romantikiliskileri-uzerine-etkisi-tez

62. Antoine P, Andreotti E, Congard A. Positive psychology intervention for couples: A pilot study. Stress and Health, 2020, 36.2: 179-190. 